\title{
In vitro evaluation of a polytope DNA construct as a novel DNA vaccine strategy against human cytomegalovirus-associated diseases
}

\author{
E. SABBAGHIAN ${ }^{1}$, F. ROODBARI ${ }^{1^{*}}$, J. AMANI $^{2}$, A. RAFIEI ${ }^{3 *}$
}

\begin{abstract}
${ }^{1}$ Department of Molecular and Cell Biology, Faculty of Basic Science, University of Mazandaran, Babolsar, Iran; ${ }^{2}$ Applied Microbiology Research Center, Baqiyatallah University of Medical Sciences, Tehran, Iran; ${ }^{3}$ Department of Immunology, Molecular and Cell Biology Research Center (MCBRC), Faculty of Medicine, Mazandaran University of Medical Sciences Sari, Iran
\end{abstract}

Received July 6, 2016; revised August 22, 2016, accepted January 8, 2017

\begin{abstract}
Summary. - Human cytomegalovirus (HCMV) establishes severe disease in fetus, newborn and immunocompromised individuals. Polytope DNA vaccine strategy allows us to choose conserved and immunodominant epitopes from different antigens that can stimulate cellular and humoral immune responses simultaneously. In this study, a synthetic chimeric gene fragment was subcloned in to DNA vaccine vector pcDNA3.1+. The recombinant vector was transferred in to suitable eukaryotic cell line HEK 293T and the expression level of polytope construct from HEK 293T-infected cells was determined by western blot. These results show that there was no mutantion in target segment and recombinant vector showed significant levels of expression. Base on these results, using a proper procedure for design can cause expression and stability of polytope peptide.
\end{abstract}

Keywords: human cytomegalovirus; polytope DNA vaccine; immunodominant epitopes; sequencing; polytope construct; overexpression

\section{Introduction}

Human cytomegalovirus with a $235 \mathrm{~kb}$ double-stranded DNA genome is the largest member in the Herpesviridae family (Zhang, 2009; Zhao et al., 2009). HCMV can be transmitted through saliva, breast feeding, placental transfer, blood transfusion, sexual contact, hematopoietic stem cell transplantation and solid organ transplantation (Dasari et al., 2013). It can cause severe clinical manifestations such as neurological disorders, developmental delay, chorioretinitis, skin lesions, visceral organomegaly and permanent disabilities. Unfortunately, among fetus and infants that have an undeveloped immune system, even death has been observed (Dollard et al., 2007; Schleiss, 2008). In some cases, increase of the risk

"Co-corresponding authors. E-mail: Roudbari@umz.ac.ir, phone: +98-113530-2424; rafiei1710@gmail.com,rafiei@mazums.ac.ir; phone: +98-11-33543614, +98-11-33257230.

Abbreviations: aa $=$ amino acid; $\mathrm{AD}=$ antigenic domain; $\mathrm{HCMV}=$ human cytomegalovirus of graft failure, morbidity and even mortality among solid organ and hematopoetic stem cell transplant recipients have also occurred (Bernstein et al., 2009; Wang et al., 2013). On the other side recent research has emphasized that HCMV may have a potential role in increasing of various inflammatory and autoimmune diseases, hepatitis, atherosclerosis, pneumonia, gastrointestinal and vascular diseases (Griffiths et al., 2015; Varani and Landini, 2011; Zheng et al., 2012). So, HCMV infection is an important public-health problem.

There are some special antiviral drugs for the disease treatment, prevention and reduction of the risk of HCMV infection in transplant individuals, but their cure rates are low and not suitable. For example, based on clear evidence in congenital infection, even with ganciclovir treatment, serious progressive hearing loss is reported (Reap et al., 2007a,b). Also some other problems, for example: drug resistance mutated strains, severe side effects, expenditure of antiviral treatment, drug toxicity and the development of viremia in patients might occur (Wloch et al., 2008).

Thus an efficient HCMV vaccine is required to reduce the need for antiviral therapy and decrease the risk of HCMV 
infection and associated diseases (Bernstein et al., 2009). Although, numerous strategies have been designed to progress vaccines against HCMV, but unfortunately no efficient vaccine has been developed yet (La Rosa and Diamond, 2012). Since adaptive immunity is fundamental for the prevention of HCMV infection, an optimal vaccine must stimulate both cellular and humoral immune responses, however cellmediated immunity response is more important (Cicin-Sain et al., 2012; Terrazzini and Kern, 2014).

Among various vaccination strategies, epitope-based vaccines (EVs) with ability to induce both humoral and cell-mediated immunity have various potential benefits over traditional vaccines, such as easy construction, safety, determined formula, chemical plainness and the capability of focusing on the most significant antigenic fragments (Oyarzun et al., 2013). Vector choice for expressing the desired genes is dependent on characteristics such as high-efficiency promoter/enhancer for high-level expression of protein and accurate termination signal. Also the selected vectors for DNA vaccine play prominent role in the type of desired immune response. For example, pVAC1-mcs and pVAC2mcs vectors are organized to elicit neutralizing antibodies (Liu, 2010; Montgomery and Prather, 2006), so they are not appropriate for this purpose and it is better to use a vector that also efficiently induces cellular immune response.

The present study was performed to assess chimeric gene construct, designed in our previous work (Sabbaghian et al., 2015). To evaluate in vitro properties of construct expression, we have subcloned insert from donor vector $\mathrm{pBMH}$ in to DNA vaccine vector pcDNA3.1+. Then, recombinant DNA vaccine vector was transfected in to appropriate eukaryotic cell line, and finally the protein expression was detected by western blot analysis.

\section{Materials and Methods}

Construction of the cloning plasmid. The designed chimeric gene (accession number KM076926) that was described previously (Sabbaghian et al., 2015) was synthesized by Biomatik Corporation (USA) and cloned into the pBMH cloning vector (Invitrogen ${ }^{\circ}$ Corp., USA) using SmaI flanking cloning site according to standard protocols. The accuracy of cloning was verified by sequencing. The gene was supplied as lyophilized DNA powder and diluted in sterile water according to reconstitution instructions.

Plasmids, bacterial strains, media and culture conditions. The eukaryotic expression shuttle vector pcDNA3.1(+) (Invitrogen) and the pBMH-insert were used for subcloning of chimeric gene. Escherichia coli strain, TOP10 competent cells (Invitrogen) were used as host for plasmids propagation.

Both plasmids were transformed to $\mathrm{CaCl}_{2}$ treated E. coli competent cells by heat shock method and recuperated in super optimal broth with catabolite repression (SOC) medium free of antibiotics at $37^{\circ} \mathrm{C}$ for $1 \mathrm{~h}$. Then transformed bacteria were grown in Luria Bertani (LB) agar medium containing $100 \mu \mathrm{g} / \mathrm{ml}$ ampicillin (Sigma-Aldrich, Germany) at $37^{\circ} \mathrm{C}$ overnight (Seidman et al., 2002). A number of surviving colonies was selected and the plasmids were extracted and purified from cells cultivated $16 \mathrm{~h}$ with shaking at $250 \mathrm{rpm}$ at $37^{\circ} \mathrm{C}$ by using Qiagen mini-prep plasmid purification kit (Qiagen, Germany) according to the manufacturer's protocols. The quantity (concentration) and quality (purity) of the isolated plasmids were validated by Nanodrop spectrophotometer (Biochrom WPA,UK) and electrophoresis on 1\% agarose gel, respectively (Brown, 2010).

Subcloning into pcDNA3.1(+) and synthesis of recombinant vector. The eukaryotic expression vector (pcDNA3.1+) and recombinant plasmid (pBMH carrying insert) were double-digested with both EcoRI and XhoI restriction enzymes (New England BioLabs, USA) at $37^{\circ} \mathrm{C}$ for $1 \mathrm{~h}$. After thermal inactivation of the enzymes, the products of digestion were electrophoresed on $1 \%$ low melting point agarose gel (Roche, Germany). The bands of desired gene and linear pcDNA3.1(+) were extracted and purified from the gel using agarose gel DNA extraction kit (Qiagen) according to instructions (Green and Sambrook, 2012).

The 723 bp desired gene was subcloned into the appropriate sites of the pcDNA3.1(+) expression vector under the control of the CMV immediate early promoter and ligated under the following reaction conditions: $100 \mathrm{ng}$ of purified digested pcDNA3.1(+) and $39 \mathrm{ng}$ of purified DNA fragments (molar ratio 1:3), $2 \mu \mathrm{l}$ of 10x ligation buffer and $0.5 \mu \mathrm{l}$ of T4 DNA ligase enzymes (New England BioLabs, USA) in $20 \mu \mathrm{l}$ total volume. This reaction was incubated at $15^{\circ} \mathrm{C}$ for $16 \mathrm{~h} .2 \mu \mathrm{l}$ of ligation product were transformed into E. coli TOP 10 competent cells and recovered in SOC medium free of antibiotic at $37^{\circ} \mathrm{C}$ for $1 \mathrm{~h}$. Next, the cells were cultivated on LB agar medium containing $100 \mu \mathrm{g} / \mathrm{ml}$ of ampicillin and incubated at $37^{\circ} \mathrm{C}$ for $16 \mathrm{~h}$ (Wu et al., 2011).

Subcloning accuracy. The plasmids from several amp $\mathrm{p}^{\mathrm{R}}$ colonies were evaluated by colony PCR (AlShahni et al., 2009). A pair of primers based on the full coding region of chimeric gene sequence was designed by the OLIGO version 7.5 primer designer and analysis software (Walker, 2007). The forward primer: 5'-ATGGCATTCATGGGCGACG-3' and reverse primer: 5'-TTACAGCTCGTCCTTGTGATGGTG-3' (CinnaGen Co, Iran) were used. The polymerase chain reaction (PCR) was performed in a total volume of $20 \mu \mathrm{l}$ reaction mixture containing of $10 \mathrm{x}$ Taq reaction buffer, $10 \mathrm{pmol} / \mathrm{l}$ of each forward and reverse primers, 1.5 $\mathrm{mmol} / \mathrm{l} \mathrm{MgCl}_{2}, 10 \mathrm{mmol} / \mathrm{l} \mathrm{dNTP} \mathrm{mix}, 5 \mathrm{U}$ of Taq DNA polymerase (Thermo Scientific, Germany) and $4 \mu \mathrm{l}$ of each bacterial colony suspension as DNA templates, using following thermal conditions: an initial denaturation at $94^{\circ} \mathrm{C}$ for $2 \mathrm{~min}$; followed by 45 cycles of $94^{\circ} \mathrm{C}$ for $30 \mathrm{~s}, 60^{\circ} \mathrm{C}$ for $45 \mathrm{~s}, 72^{\circ} \mathrm{C}$ for $1 \mathrm{~min}$, and final extension was carried out at $72^{\circ} \mathrm{C}$ for $7 \mathrm{~min}$. The reactions were cycled in a thermal cycler (Bio-Rad, USA) and the PCR products were analyzed using electrophoresis on $1 \%$ agarose gel and visualized by SYBR green dye.

After selecting a number of recombinant colonies which were confirmed by colony PCR, the plasmids were extracted from the 
cells cultured overnight and verified by restriction digestion (with both EcoRI and XhoI enzymes), followed by nucleotide sequencing using CMV-F forward and $\mathrm{pQE}-\mathrm{F}$ reverse universal primers (MacroGen, South Korea) to verify that chimeric gene is cloned in the correct orientation (Wu et al., 2011).

Transfection and expression of recombinant plasmid in mammalian cells. Human embryonic kidney 293T (HEK 293T) cell line was purchased from national Cell line bank (Pasteur Institute, Tehran, Iran). The cells were preserved in the appropriate conditions recommended by American type culture collection (ATCC). Cells were cultured in RPMI 1640 (PAA, Pasching/Austria) supplemented with $10 \%$ inactivated fetal calf serum (PAA, Pasching/Austria), penicillin $(100 \mathrm{U} / \mathrm{ml})$, streptomycin $(100 \mu \mathrm{g} / \mathrm{ml})$ and L-glutamine ( $300 \mathrm{mg} / \mathrm{l}$ ) in $5 \% \mathrm{CO}_{2}$ at $37^{\circ} \mathrm{C}$ in an incubator (Memmert, Germany) under $50 \%$ humidity.

$5 \times 10^{5}$ HEK 293T cells were seeded in 24-well plates with $1 \mathrm{ml}$ media and incubated for $24 \mathrm{~h}$ until $70 \%-90 \%$ confluency. Then, the cells were transiently transfected with the recombinant plasmid by TurboFect transfection reagent (Invitrogen) according to the manufacturer's suggestion. The HEK-293T transfected with pcDNA3.1(+) without insert (plasmid control), un-transfected cells (negative control) and a $25 \mathrm{kDa}$ purified protein with Poly His-Tag (positive control) were used for verification by western blot. Then, gene expression in transfected cells was evaluated by SDS-PAGE and immunoblotting analysis (Kim and Eberwine, 2010).

SDS-PAGE and Western blot analysis. The transfected and untransfected cells were harvested $72 \mathrm{~h}$ post transfection, and subsequently lysed. Briefly, the cells were rinsed two times with ice-cold DEPS-treated CMF $\left(\mathrm{Ca}^{2+} / \mathrm{Mg}^{2+}\right.$ Free-Dulbecco's phosphate buffered saline, $\mathrm{pH}$ 7.4) (PAA, Pasching/Austria), trypsinized, scraped off, and centrifuged at $1,800 \mathrm{rpm}$ for $5 \mathrm{~min}$ at $4^{\circ} \mathrm{C}$. Approximately 2.5 $\times 10^{6}$ cells were resuspended on ice in $1 \mu$ ice-cold sterilized RIPA cell lysis buffer (Santa Cruz Biotechnology, USA) containing 2 $\mathrm{mmol} / \mathrm{l}(10 \mu \mathrm{l})$ phenylmethylsulfonyl fluoride (PMSF), $1 \mathrm{mmol} / \mathrm{l}$ (10 $\mu \mathrm{l})$ sodium orthovanadate, and $10 \mu \mathrm{l}$ protease inhibitor cocktail (Santa Cruz Biotechnology, USA). After homogenization by several passages through a 21-gauge needle and incubation for 20 $\mathrm{min}$ on ice, the lysis mixture was centrifuged at $10,000 \times \mathrm{g}$ for 10 min at $4^{\circ} \mathrm{C}$, cell debris was removed and the clarified supernatant was transferred to a sterile microtube and then stored at $-80^{\circ} \mathrm{C}$ for future use (Germano and Driscoll 2011). Each cell lysate was incubated in $6 \times$ sample loading buffer $(375 \mathrm{mmol} / \mathrm{l}$ Tris- $\mathrm{HCl}(\mathrm{pH}$ 6.8), $12 \%(\mathrm{w} / \mathrm{v})$ SDS, $50 \%(\mathrm{v} / \mathrm{v})$ glycerol, $30 \%$ 2-mercaptoethanol and $0.012 \%(\mathrm{w} / \mathrm{v})$ Bromophenol blue) for $10 \mathrm{~min}$ at $75^{\circ} \mathrm{C}$. Boiled cell lysates were loaded onto a $12 \%$ SDS-PAGE electrophoresis in Mini-PROTEAN ${ }^{\circledR}$ Tetra handcast systems (Bio-Rad), according to the standard procedures (Gallagher, 2008). The separated proteins were directly blotted onto a PVDF membrane (Santa Cruz Biotechnology) in transfer buffer ( $25 \mathrm{mmol} / \mathrm{l}$ tris, $190 \mathrm{mmol} / \mathrm{l}$ glycine ( $\mathrm{pH}$ 8.3 ) with $20 \%$ methanol) using a wet electrotransfer cell (Bio-Rad) at $100 \mathrm{~V}$ for $1 \mathrm{~h}$ at $4^{\circ} \mathrm{C}$ (Gallagher et al., 2008). The membrane was blocked with $3 \%(\mathrm{w} / \mathrm{v})$ skimmed dried milk diluted in Tris-buffered saline with Tween 20 (TBST washing buffer) $(200 \mathrm{mmol} / \mathrm{l}$ Tris- $\mathrm{HCl}$ adjust to $\mathrm{pH} 7.5,9 \%(\mathrm{w} / \mathrm{v}) \mathrm{NaCl}, 0.05 \%$ Tween 20$)$ for overnight at $4^{\circ} \mathrm{C}$, followed by washing in TBST three times. The membrane was additionally probed with $2 \mu \mathrm{l}$ of mouse monoclonal anti-PolyHistidine-HRP antibody (Sigma-Aldrich) by dilution of 1:2,000 in TBST with $3 \%$ skimmed dried milk for $5 \mathrm{~h}$ with shaking at room temperature. After rinsing, with TBST for three times, the blot was visualized using an ECL detection kit (Enhanced chemiluminescence reagents, Amersham Pharmacia biotech, UK) by G BOX (Syngene, UK) device (Germano and Driscoll 2011).

\section{Results}

Subcloning of the chimeric synthetic gene in pcDNA3.1(+)

Purified bands with a good concentration and quality on agarose gel were used for ligation reaction (Fig. 1). The synthetic gene was inserted into EcoRI and XhoI double-digested vector (Fig. 2). Followed by transformation and plating of the bacterial cells on LB agar containing the selective antibiotic and present colonies were considered positive.

\section{The subcloning accuracy evaluation}

Several transformed surviving colonies were evaluated by colony PCR with the chimeric gene specific primers. The positive randomly picked plasmids were confirmed

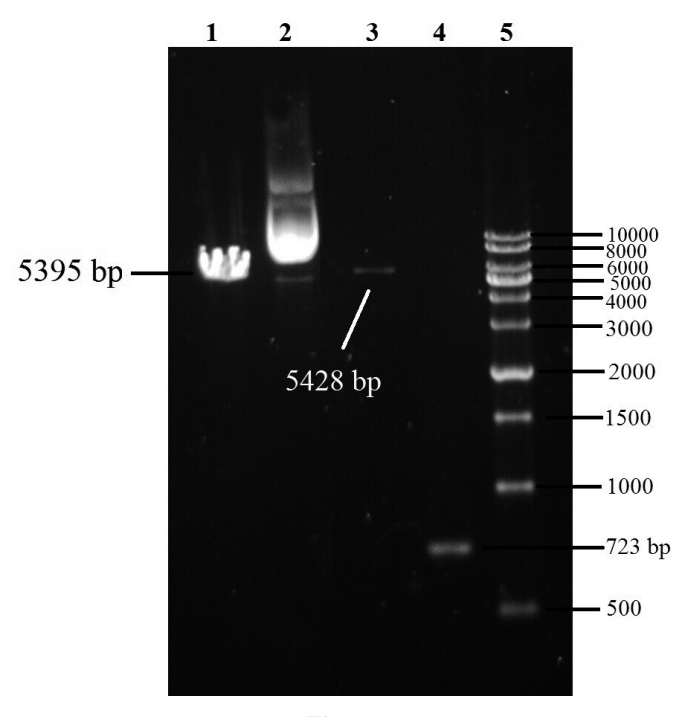

Fig. 1

Gel electrophoretic pattern of digestion products and purified plasmids on $1 \%$ agarose gel

Purified pcDNA3.1(+) double digested with EcoRI and XhoI restriction enzymes (line 1), purified pcDNA3.1(+) undigested (line 2), pcDNA3.1(+) single fragment with XhoI restriction enzyme (line 3), purified insert (line 4), $1 \mathrm{~kb}$ DNA ladder Fermentas (line 5). 
(a)

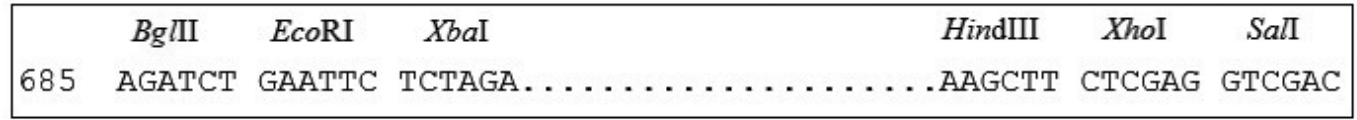

(b)

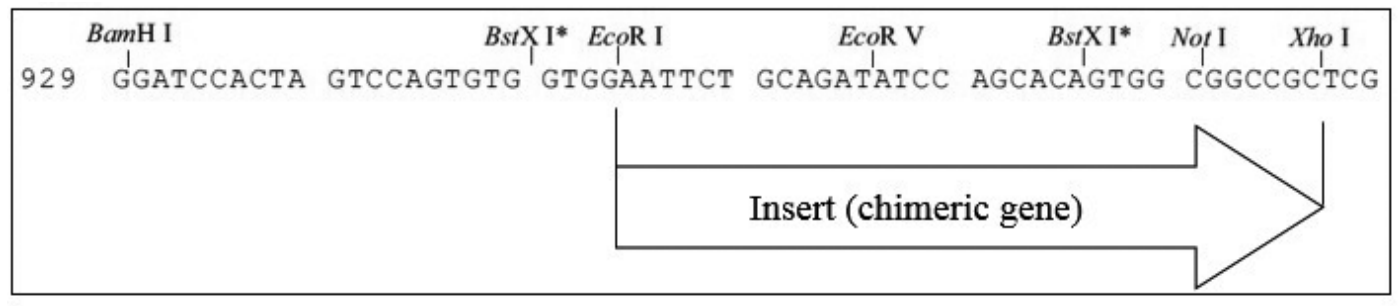

Fig. 2

Location of insert in pBMH and map of pcDNA3.1-MCS

Insert in pBMH (donor plasmid) consists of 685-1408 nucleotides (a). The chimeric synthetic gene was inserted between EcoRI and XhoI restriction sites in pcDNA 3.1(+) multi cloning site (recipient plasmid) (sequence shown 929-988) (b).

by double digestion and were analyzed on 1\% agarose gel electrophoresis and subsequently by sequencing. Sequence analysis verification was done by Chromas Lite software. There were no mutations and amplification errors in the sequence of cloned chimeric synthetic gene and the sequence revealed $100 \%$ homology with sequence that is presented in GenBank (Acc. No. KM076926).

The correct fragment pattern of restriction analysis of the plasmid on agarose gel electrophoresis proved the cloning accuracy. The recombinant pcDNA3.1(+) digested with SacI restriction enzyme, demonstrated two fragments (109, 6042 bp) (Fig. 3), whereas non-recombinant pcDNA3.1(+)

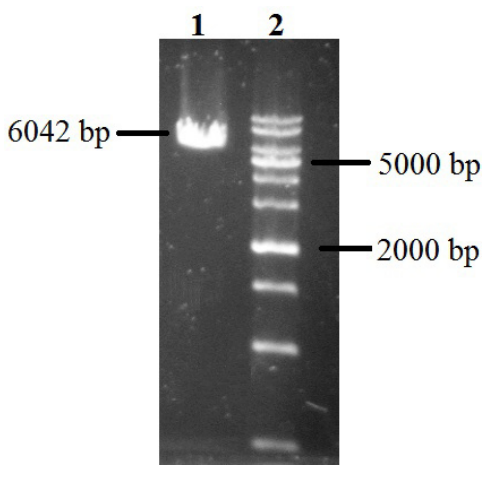

Fig. 3

Confirmation of subcloning by restriction analysis Purified recombinant pcDNA3.1(+) digested with SacI restriction enzyme has yielded fragment with 6042 bp (line 1) (109 bp fragment not shown), $1 \mathrm{~kb}$ DNA ladder Fermentas (line 2). digestion with SacI restriction enzyme, demonstrated two fragments $(109,5319 \mathrm{bp})$. These confirmations proved that target sequence was successfully inserted between the EcoRI

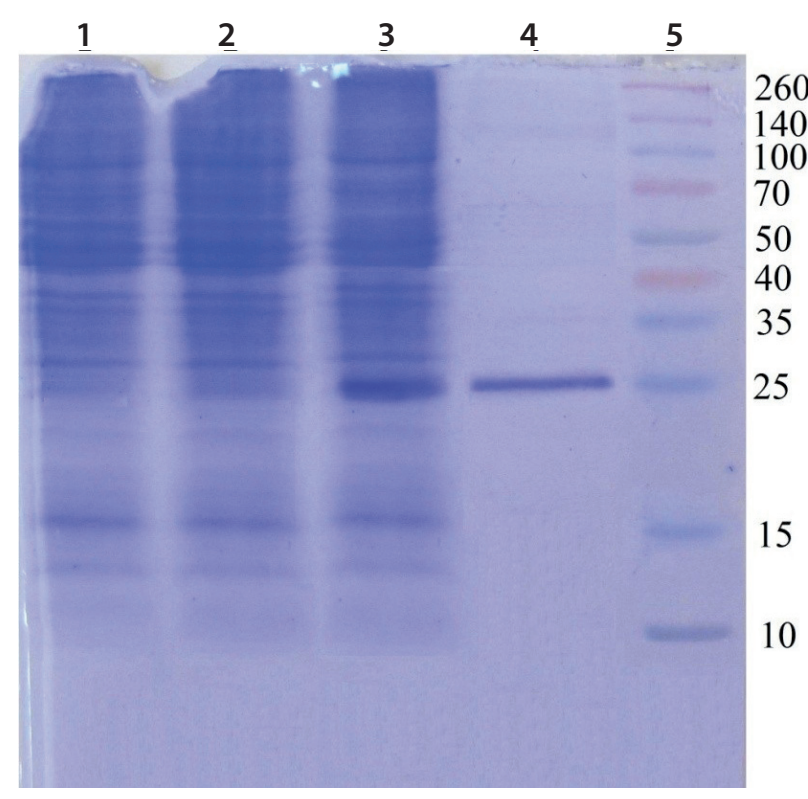

Fig. 4

SDS-PAGE of cell lysates visualized with Coomassie blue G-250 The untransfected cell lysate (negative control) (line 1), the lysate of transfected cells with non-recombinant pcDNA3.1(+) (plasmid control) (line 2), expression of native protein in HEK-239T cells (line 3), purified $25 \mathrm{kDa}$ protein with Poly-His Tag (positive control) (line 4), protein molecular weight marker Fermentas (10-260 kDa) (line 5). 


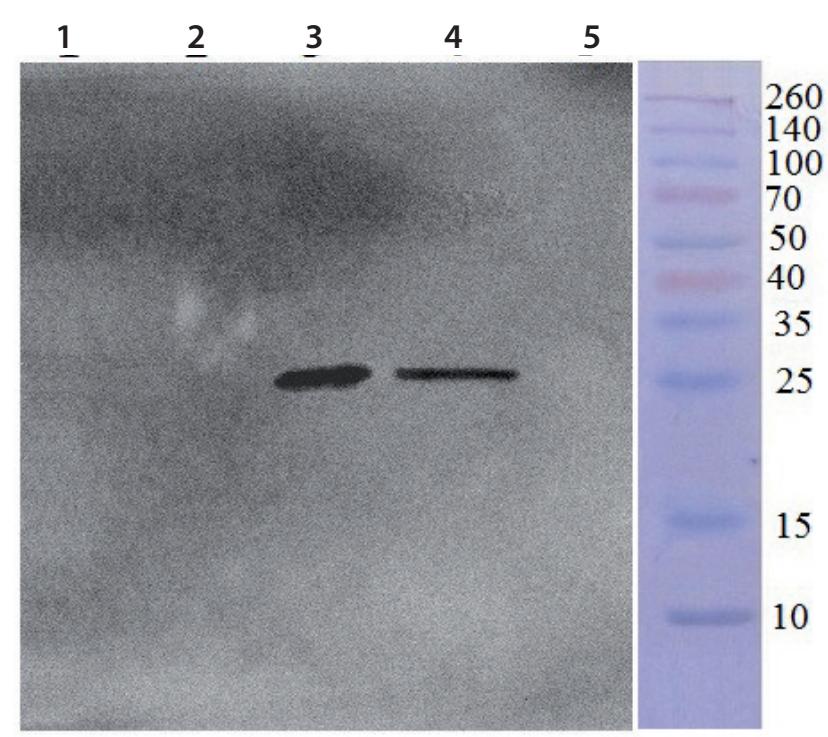

Fig. 5

Western blot analysis of the expressed protein, using mouse monoclonal anti-Poly-Histidine-HRP antibody

The untransfected cell lysate (negative control) (line 1), the lysate of transfected cells with non-recombinant pcDNA3.1(+) (plasmid control) (line 2), expression of native protein in HEK-239T cells (line 3), purified $25 \mathrm{kDa}$ protein with Poly-His Tag (positive control) (line 4), protein molecular weight marker Fermentas (10-260 kDa) (line 5).

and XhoI restriction sites of the expressing eukaryote DNA vaccine vector.

\section{SDS-PAGE and western blot analysis}

Western blot analysis was used to indicate the in vitro expression of the recombinant pcDNA3.1(+) at $72 \mathrm{~h}$ post transient transfection of HEK-293T cells. Analysis of cell lysates by SDS-PAGE and western blot showed a $25 \mathrm{kDa}$ band equivalent to the native protein, which confirmed that the HEK-239T cells were successfully transfected and the chimeric synthetic construct, was sufficiently expressed as a native protein under the control of the CMV immediate early promoter. As opposed to, no immunoreactive material was found in the lysate of cells transfected with non-recombinant pcDNA3.1(+) (plasmid control) and untransfected HEK-293T cells (negative control) as indicated in Figs. 4 and 5.

\section{Discussion}

Human cytomegalovirus establishes severe disease or mortality in fetus, newborn and immunosuppressed individuals. For example, substantiated evidence reveals that only in the USA, 40,000 babies are born with congenital severe infection each year (Dasari et al., 2013). Because of the widespread transmission and despite antiviral drugs, the need to provide an effective vaccine to prevent the spread of cytomegalovirus infection is strongly needed. Many studies have been done to develop vaccines against HCMV. But in spite of increasing global efforts to develop a vaccine specific against HCMV has not been registered yet (Schleiss, 2008).

DNA vaccination represents a potentially significant novel approach for the elicitation of protective immunity against a broad range of protein antigens and is the most common strategy for HCMV vaccine. Polytope DNA vaccines, conserved and immunodominant epitopes from different antigens, are suitable alternative strategy, which stimulates both cellular and humoral immune responses simultaneously (Sabet et al., 2014). Thus, in this study, polytope DNA vaccine strategy as a new generation of efficient DNA vaccines was selected. In continuation of in silico studies that have been described previously (Sabbaghian et al., 2015), we evaluated expression of polytope DNA vaccine in vitro.

The basis for design of highly immunogenic multimeric polytope construct is to choose appropriate virulence factors among all of the pathogen antigens, and then immunodominant epitope selection with its protective immune response induction (Oyarzun et al., 2013).

In this vaccine, epitopes have been chosen from envelope glycoprotein B (gB) and tegument phosphoprotein (pp65, pp150) (Sabbaghian et al., 2015). In accordance with pathogenesis mechanism of this virus suitable targets for inhibition of efficient virulence factors are needed. gB protein responsible for forceful in virion attachment, cell-cell fusion process and cell-to-cell spread, protein pp65 responsible for drastic immune evasion and protein pp150 essential for maintaining the stability of the cytoplasmic capsids, reorganization of the cytoplasmic compartment during virion assembly and egress of virus particles can be ideal targets for designing an effective vaccine against HCMV (Gicklhorn et al., 2003; Tomtishen, 2012).

It was found that up to $70 \%$ of serum-neutralizing antibodies in all sera from HCMV-seropositive specimens were directed against gB (Britt et al., 1990). Recombinant vaccines based on $\mathrm{gB}$ against disease in guinea pig and murine models of HCMV infection were found to have high efficacy. This finding provides more endorse for human efficacy testing (Rapp et al., 1994). Cellular immune responses against HCMV tegument proteins, with most emphasis focused on the pp65 tegument protein, are advised in vaccination strategies aimed to eliciting the majority of CD8+ T lymphocyte responses (McLaughlin-Taylor et al., 1994; Wills et al., 1996). Also it was observed that adoptive transfer of pp65-specific cytotoxic T lymphocyte (CTL) improves HCMV symptom disease in high-risk transplant 
cases. This observation provides further attention for pp65based vaccines (Walter et al., 1995). Pass et al. revealed that HCMV envelope glycoprotein B is the major target of neutralizing Abs and the best choice for the subunit HCMV vaccine (Pass et al., 1999). In an another publication it has been reported that pp65 and pp150-specific CTLs were detected in a considerable percentage of $92 \%$ and $45 \%$ of naturally seropositive healthy donors respectively, which is consistent with previous reports. The gB-specific $\mathrm{CD}^{+}$ lymphocytes have also been detected in $30 \%$ of seropositive donors (Gyulai et al., 2000).

Indiscriminate and immunodominant epitope identification plays a crucial role in immunoinformatics and epitope-based vaccine design. Britt reported the C- (gp58) and N-terminal (gp116) fragments of gB were two linear epitopes and antibody binding sites (Ohlin et al., 1993). In another research it has been reported that the gB sequence is severely conserved (high degree of homology 95-98\%) among different HCMV isolates, and two potential sites (antigenic domain 2 (AD2) of gB located between amino acid aa 27 to 84 in N-terminal and AD1 between aa 549 to 645 in C-terminal) for neutralizing antibody stimulation has been shown (Beninga et al., 1995; Wagner et al., 1992). Three antibody-binding domains on gB molecule, an extracellular immunodominant AD-1 located between aa 552-635; AD-2 (aa 50-86), composed of site I (aa 50-54) and site II (67-86); and AD-3 located between aa 798-805 were determined. Of the three domains, only AD-1 and site II of AD-2 have been confirmed to stimulate virusneutralizing antibodies (Gicklhorn et al., 2003). Based on enzymatic degradation studies of gB, Ohlin et al. had shown that methionines located at residues 541, 564, and 635 may be efficacious in the folding of the epitope recognized by the gB-specific antibodies and peptides between these positions are consequential for antibody binding (Ohlin et al., 1993). Additional studies have demonstrated that internal deletions in the gB sequence (aa 560-640) resulted in loss of AD-1 expression (Britt et al., 2005). In accordance with these previous experiments, with regards to epitope selection, AD2 aa 27-86 and AD1 aa 540-645 have been preferred. So we delineated a novel synthetic polytope construct based on five immunodominant human-restricted cellular and humoral epitopes derived from HCMV structural antigens.

In DNA vaccine, the selected vectors play important role in type of immune response stimulation. The pcDNA3.1 plasmid that is one of the most widely used mammalian gene expression vector was used in this study. We have taken all necessary measures (such as proper selection of epitope sequence, codon optimization and selection of the appropriate vector and promoter) to increase expression. The results show that using a proper strategy for design can enable expression and stability of polytope peptide.
Acknowledgements. The authors would like to thank the staff of the Molecular and Cell biology research center, faculty of medicine, Mazandaran University of medical sciences, Sari, Iran. All authors have read and endorsed the final manuscript.

\section{References}

AlShahni MM, Makimura K, Yamada T, Satoh K, Ishihara Y, Takatori K, Sawada T (2009): Direct colony PCR of several medically important fungi using Ampdirect plus. Jpn. J. Infect. Dis. 62, 164-167.

Beninga J, Kropff B, Mach, M (1995): Comparative analysis of fourteen individual human cytomegalovirus proteins for helper T cell response. J. Gen. Virol. 76, 153-160. https:// doi.org/10.1099/0022-1317-76-1-153

Bernstein DI, Reap EA, Katen K, Watson A, Smith K, Norberg P, Olmsted RA, Hoeper A, Morris J, Negri S, Maughan MF, Chulay JD (2009): Randomized, double-blind, Phase 1 trial of an alphavirus replicon vaccine for cytomegalovirus in CMV seronegative adult volunteers. Vaccine 28, 484-493. https://doi.org/10.1016/j.vaccine.2009.09.135

Britt WJ, Jarvis MA, Drummond DD, Mach M (2005): Antigenic domain 1 is required for oligomerization of human cytomegalovirus glycoprotein B. J. Virol. 79, 4066-4079. https://doi.org/10.1128/JVI.79.7.4066-4079.2005

Britt WJ, Vugler L, Butfiloski EJ, Stephens EB (1990): Cell surface expression of human cytomegalovirus (HCMV) gp55-116 $(\mathrm{gB})$ : use of HCMV-recombinant vaccinia virus-infected cells in analysis of the human neutralizing antibody response. Virol. J. 64, 1079-1085.

Brown TA (2010): Purification of DNA from living cells: Gene Cloning and DNA Analysis: An Introduction, Vol. 338. Wiley-Blackwell Publishing, pp. 25-34.

Cicin-Sain L, Brien JD, Uhrlaub JL, Drabig A, Marandu TF, Nikolich-Zugich J (2012): Cytomegalovirus infection impairs immune responses and accentuates T-cell pool changes observed in mice with aging. PLoS Pathog. 8, e1002849. https://doi.org/10.1371/journal.ppat.1002849

Dasari V, Smith C, Khanna, R (2013): Recent advances in designing an effective vaccine to prevent cytomegalovirus-associated clinical diseases. Expert Rev. Vaccines. 12, 661-676. https://doi.org/10.1586/erv.13.46

Dollard SC, Grosse SD, Ross DS (2007): New estimates of the prevalence of neurological and sensory sequelae and mortality associated with congenital cytomegalovirus infection. Rev. Med. Virol. 17, 355-563. https://doi. org/10.1002/rmv.544

Gallagher S, Winston SE, Fuller, SA (2008): Immunoblotting and immunodetection: Current Protocols in Immunology, Vol. 10. pp. 8.10.1-8.10.24.

Gallagher SR (2008): SDS-polyacrylamide gel electrophoresis (SDS-PAGE). In Wiley EA (Ed.): Current Protocols Essential Laboratory Techniques, pp. 7.3.1-7.3.10. https:// doi.org/10.1002/9780470089941.et0703s00

Germano S, Driscoll LO (2011): Western blotting analysis as a tool to study receptor tyrosine kinases. In Driscoll LO 
(Ed.): Gene Expression Profiling Methods and Protocols. Vol. 784. Humana Press, pp. 109-121. https://doi. org/10.1007/978-1-61779-289-2 8

Gicklhorn D, Eickmann M, Meyer G, Ohlin M, Radsak K (2003): Differential effects of glycoprotein $B$ epitope-specific antibodies on human cytomegalovirus-induced cellcell fusion. J. Gen. Virol. 84, 1859-1862. https://doi. org/10.1099/vir.0.19017-0

Green MR, Sambrook J (2012): Gel Electrophoresis of DNA and Pulsed-Field Agarose: Molecular Cloning: A Laboratory Manual. Vol. 2. Cold Spring Harbor Laboratory Press, New York, pp. 444-453.

Griffiths P, Baraniak I, Reeves M (2015): The pathogenesis of human cytomegalovirus. J. Pathol. 235, 288-297. https:// doi.org/10.1002/path.4437

Gyulai Z, Endresz V, Burian K, Pincus S, Toldy, J, Cox WI, Meric C, Plotkin S, Gonczol E, Berencsi K (2000): Cytotoxic $\mathrm{T}$ lymphocyte (CTL) responses to human cytomegalovirus pp65, IE1-Exon4, gB, pp150, and pp28 in healthy individuals: reevaluation of prevalence of IE1specific CTLs. J. Infect. Dis. 181, 1537-1546. https://doi. org/10.1086/315445

Kim TK, Eberwine JH (2010): Mammalian cell transfection: the present and the future. Anal. Bioanal. Chem. 397, 31733178. https://doi.org/10.1007/s00216-010-3821-6

La Rosa C, Diamond DJ (2012): The immune response to human CMV. Future Virol. 7, 279-293. https://doi.org/10.2217/ fvl.12.8

Liu MA (2010): Immunologic basis of vaccine vectors. Immunity 33, 504-515. https://doi.org/10.1016/j.immuni.2010.10.004

McLaughlin-Taylor E, Pande H, Forman SJ, Tanamachi B, Li CR, Zaia JA, Riddell SR (1994): Identification of the major late human cytomegalovirus matrix protein pp65 as a target antigen for CD8+ virus-specific cytotoxic T lymphocytes. J. Med. Virol. 43, 103-110. https://doi.org/10.1002/ jmv.1890430119

Montgomery DL, Prather KJ (2006): Design of plasmid DNA constructs for vaccines: DNA Vaccines. Vol. 127. Springer International Publishing, pp. 11-22. https://doi. org/10.1385/1-59745-168-1:11

Ohlin M, Sundqvist VA, Mach M, Wahren B, Borrebae CA (1993): Fine specificity of the human immune response to the major neutralization epitopes expressed on cytomegalovirus gp58/116 (gB), as determined with human monoclonal antibodies. J. Virol. 67, 703-710.

Oyarzun P, Ellis JJ, Boden M, Kobe B (2013): PREDIVAC: CD4+ Tcell epitope prediction for vaccine design that covers $95 \%$ of HLA class II DR protein diversity. BMC Bioinformatics 14, 52. https://doi.org/10.1186/1471-2105-14-52

Pass RF, Duliege AM, Boppana S, Sekulovich R, Percell S, Britt W, Burke RL (1999): A subunit cytomegalovirus vaccine based on recombinant envelope glycoprotein $\mathrm{B}$ and a new adjuvant. J. Infect. Dis. 180, 970-975. https://doi. org/10.1086/315022

Rapp M, Lucin P, Messerle M, Loh LC, Koszinowski UH (1994): Expression of the murine cytomegalovirus glycoprotein H by recombinant vaccinia virus. Gen. Virol. 75, 183-188. https://doi.org/10.1099/0022-1317-75-1-183
Reap EA, Dryga SA, Morris J, Rivers B, Norberg PK, Olmsted RA, Chulay JD (2007a): Cellular and humoral immune responses to alphavirus replicon vaccines expressing cytomegalovirus pp65, IE1, and gB proteins. Clin. Vaccine Immunol. 14, 748-755. https://doi.org/10.1128/ CVI.00037-07

Reap EA, Morris J, Dryga SA, Maughan M, Talarico T, Esch RE, Negri S, Burnett B, Graham A, Olmsted RA, Chulay JD (2007b): Development and preclinical evaluation of an alphavirus replicon particle vaccine for cytomegalovirus. Vaccine 25, 7441-7449. https://doi.org/10.1016/j. vaccine.2007.08.016

Sabbaghian E, Roodbari F, Rafiei A, Amani J (2015): In silico design of a multimeric polytope as a highly immunogenic DNA vaccine against human cytomegalovirus. J. Appl. Biotechnol. Rep. 1, 14--153.

Sabet LP, Taheri T, Memarnejadian A, Azad TM, Asgari F, Rahimnia R, Alavian SM, Rafati S, Rad KS (2014): Immunogenicity of multi-epitope DNA and peptide vaccine candidates based on core, E2, NS3 and NS5B HCV epitopes in BALB/c mice. Hepat. Mon. 14, e22215.

Schleiss MR (2008): Cytomegalovirus vaccine development. Curr. Top. Microbiol. Immunol. 325, 361-382. https://doi. org/10.1007/978-3-540-77349-8 20

Seidman CE, Struhl K, Sheen J, Jessen T (2002): Introduction of plasmid DNA into cells. In Ausubel FM, Brent R, Kingston RE, Moore DD, Seidman JG, Smith JA, Struhl K (Eds): Short Protocols in Molecular Biology: A Compendium of Methods from Current Protocols in Molecular Biology. Vol. 2. Wiley New York, pp. 1.8.1-1.8.10.

Terrazzini N, Kern F (2014): Cell-mediated immunity to human CMV infection: a brief overview. F1000Prime Rep. 6, 28. https://doi.org/10.12703/P6-28

Tomtishen JP (2012): Human cytomegalovirus tegument proteins (pp65, pp71, pp150, pp28). Virol. J. 9, 22. https://doi. org/10.1186/1743-422X-9-22

Varani S, Landini MP (2011): Cytomegalovirus-induced immunopathology and its clinical consequences. Herpesviridae 2, 6. https://doi.org/10.1186/2042-4280-2-6

Wagner B, Kropff B, Kalbacher H, Britt W, Sundqvist Va, Ostberg L, Mach M (1992): A continuous sequence of more than 70 amino acids is essential for antibody binding to the dominant antigenic site of glycoprotein gp58 of human cytomegalovirus. J. Virol. 66, 5290-5297.

Walker JM (2007): PCR primer design. In Yuryev A (Ed.): Methods in Molecular Biology, Vol. 402. Springer, pp. 35-79.

Walter EA, Greenberg PD, Gilbert MJ, Finch RJ, Watanabe KS, Thomas ED, Riddell SR (1995): Reconstitution of cellular immunity against cytomegalovirus in recipients of allogeneic bone marrow by transfer of T-cell clones from the donor. N. Engl. J. Med. 333, 1038-1044. https://doi. org/10.1056/NEJM199510193331603

Wang H, Yao Y, Huang C, Che Q, Chen J, Chen Z (2013): Immunization with cytomegalovirus envelope glycoprotein $\mathrm{M}$ and glycoprotein N DNA vaccines can provide mice with complete protection against a lethal murine cytomegalovirus challenge. Virol. Sin. 28, 174-182. https://doi. org/10.1007/s12250-013-3330-9 
Wills MR, Carmichael AJ, Mynard K, Jin X, Weekes MP, Plachter B, Sissons, JG (1996): The human cytotoxic T-lymphocyte (CTL) response to cytomegalovirus is dominated by structural protein pp65: frequency, specificity, and T-cell receptor usage of pp65-specific CTL. J. Virol. 70, 7569-7579.

Wloch MK, Smith LR, Boutsaboualoy S, Reyes L, Han C, Kehler J, Smith HD, Selk L, Nakamura R, Brown JM, Marbury T, Wald A, Rolland A, Kaslow D, Evans T, Boeckh M (2008): Safety and immunogenicity of a bivalent cytomegalovirus DNA vaccine in healthy adult subjects. J. Infect. Dis. 197, 1634-1642. https://doi.org/10.1086/588385

Wu W, Zhang HH, Welsh MJ, Kaufman PB (2011): Subcloning of genes or DNA fragments: Gene Biotechnology, Third Edition. CRC Press, pp. 73-96.
Zhang Y (2009): Protein structure prediction: when is it useful? Curr. Opin. Struct. Biol. 19, 145-155. https://doi. org/10.1016/j.sbi.2009.02.005

Zhao P, Ma D, Yan S, Shao N, Zhang J, Bi Z, Dai J, Ji M, Ji C (2009): Towards a novel vaccine against human cytomegalovirus based on a chimeric Ad5F35 adenovirus vector expressing the immunodominant antigenic domain 1 epitope. Intervirology 52, 35-42. https://doi. org/10.1159/000212989

Zheng Q, Tao R, Gao H, Xu J, Shang S, Zhao N (2012): HCMVencoded UL128 enhances TNF-alpha and IL-6 expression and promotes $\mathrm{PBMC}$ proliferation through the MAPK/ ERK pathway in vitro. Viral Immunol. 25, 98-105. https:// doi.org/10.1089/vim.2011.0064 